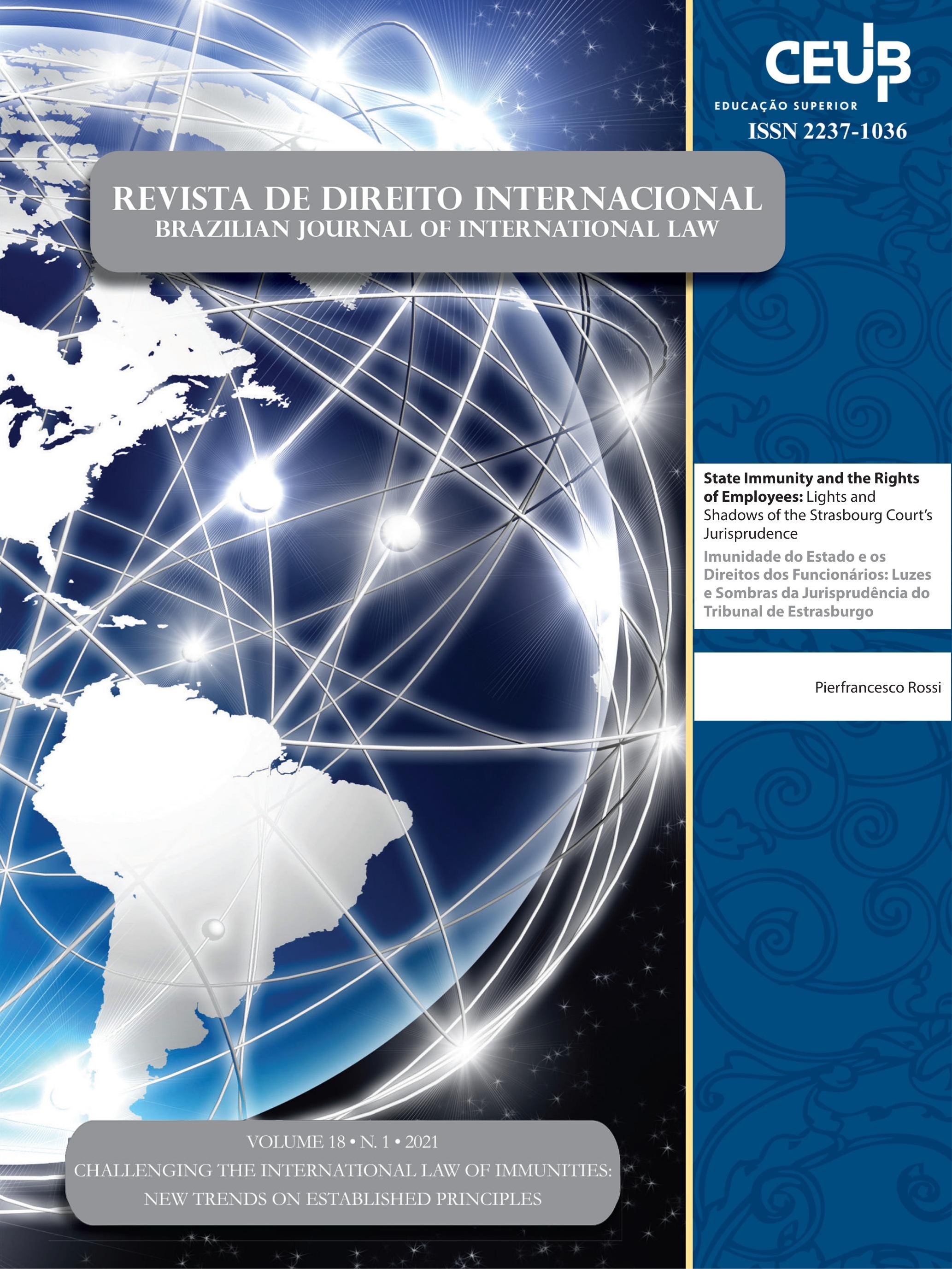


EDITORIAL

Challenging the International Law of Immunities: New Trends on Established Principles? An introduction to the special issue ............................................ 14

Lucas Carlos Lima, Loris Marotti e Paolo Palchetti

CrôniCAS........................................................................................ 17

RESPONSABILIDADE E IMUNIDADE DAS ORgANIZAÇÕES INTERNACIONAIS: PRÁTICA E DESAFIOS ...19 Vinícius Fox Drummond Cançado Trindade

The JURISDiCTIONAL IMMUNITY OF INTERNATIONAL ORgaNiZATIONS BEFORE THE BRAZILIAN SuPREMe Federal Court.

Bárbara Tuyama Sollero

The Law of State Immunity before the Brazilian Supreme Court: what is at stake WITH THE "ChANGRI-LA" CASE?

Aziz Tuffi Saliba e Lucas Carlos Lima

\section{Dossiê: Challenging the International Law of Immunities: New Trends} on Established Principles?

State Immunity and the Rights of Employees: Lights and Shadows of the Strasbourg COURT's JURISPRUdENCE .61

Pierfrancesco Rossi

A human Rights-BASEd CHALlENGE: THE KEY TO UNLOCK THE UN'S IMMUNiTY PROBLEM?...79 Héloïse Guichardaz

IMMUNITIES OF STATE OFFICIALS AND THE "FUNDAMENTALLY DIFFERENT NATURE" OF INTERNATIONAL COURTS: THE APPEALS CHAMBER DECISION IN THE JORDAN REFERRAL RE AL BASHIR ...97 Rita Guerreiro Teixeira e Hannes Verheyden 
IMUNIDADE DE JURISDIÇÃo dOS EsTADOS: O CAMINHO PARA A RELATIVIZAÇÃo

Vinícius Assis da Silveira, Luiz Felipe Costa Santana e Valesca Raizer Borges Moschen

The IMmUNity OF INTERNATIONAL ORganizations IN LABOUR DispUTES. DeVElopments BEFORE INTERNATIONAL TRIBUNALS, NATIONAL COURTS AND THE COLOMBIAN JURISDICTION ..... 137 Walter Arévalo-Ramirez e Ricardo Abello-Galvis

Imunidade de Jurisdição dos Estados E Poder Executivo brasileiro: os Pareceres dos CONSULTORES JURÍDICOS DO ITAMARATY

George Rodrigo Bandeira Galindo

Artigos SOBRe outros temas

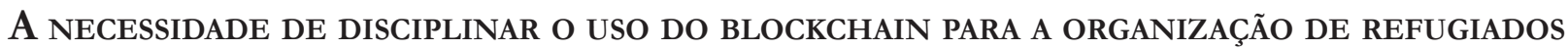
PELO DIREITO INTERNACIONAL. 195

Agatha Gonçalves Santana, Carla Noura Teixeira e Otavio Noura Teixeira

O TRABALHO INFANTIL DE MIGRANTES E REFUgIADOS VENEZUELANOS NO BRASIL

André Viana Custódio e ohana Cabral

THE NEW BRAZILIAN ANTI-TRAFFICKING LAW: CHALLENGES AND OPPORTUNITIES TO COVER THE NORMATIVE LACK . 243 Waldimeiry Correa da Silva

¿SON PARTE DEL BLOQUE DE CONSTITUCIONALIDAD LOS TRATADOS INTERNACIONALES DE DERECHOS HuMANOS DE LA OEA EN CHILE?: AVANCES EN BASE A LA DOCTRINA, NORMATIVA Y JURISPRUDÊNCIA. 270

Juan Pablo Díaz Fuenzalida

O Tratado de Saint-Germain-En-Laye e os Efeitos do instituto da “opÇão” Sobre a CONDIÇÃO JURÍDICA DOS DESCENDENTES DE CIDADÃOS AUSTRÍACOS TRENTINO-TIROLÊSES ......290 Arno Dal Ri Jr. e Andrey José Taffner Fraga

Control Judicial de la Corte Interamericana de Derechos Humanos y Programas Masivos de Reparaciones: Hacia un Enfoque más Matizado .309 Juan Carlos Ochoa-Sánchez 
JuSTICIABILIDADE DIRETA DOS DIREITOS ECONÔMICOS, SOCIAIS, CULTURAIS E AMBIENTAIS NA

Corte Interamericana DE Direitos Humanos..........................................................334

Augusto Antônio Fontanive Leal e Guilherme Massaú

How the indigenous case of Xukuru before the Inter-American Court of Human RiGHTS CAN INSPIRE DECOLONIAL COMPARATIVE STUDIES ON PROPERTY RIGHTS..........................353

Flavianne Fernanda Bitencourt Nóbrega e Camilla Montanha 


\title{
State Immunity and the Rights of Employees: Lights and Shadows of the Strasbourg Court's Jurisprudence*
}

\author{
Imunidade do Estado e os Direitos \\ dos Funcionários: Luzes e Sombras da \\ Jurisprudência do Tribunal de Estrasburgo
}

Pierfrancesco Rossi**

\section{Abstract}

This paper analyzes the case law of the European Court of Human Rights on the relationship between state immunity and foreign state employees' right of access to a court, protected under Article 6 of the European Convention on Human Rights. While acknowledging that the case law of the Strasbourg Court has in many respects contributed to providing employees of foreign states with broader access to the courts of receiving states, the paper submits that the Court's handling of labour cases presents some major flaws. Namely, it is argued that (i) the Court's assessment of the norms of customary international law in the area of state immunity from employment lawsuits is ill-proven and largely unconvincing; (ii) this flawed assessment of custom has had a negative impact on the scope of employees' right of access to a court; and (iii) under the approach followed by the Strasbourg Court, certain categories of state employees may be left without any judicial means of obtaining redress. It appears crucial that the Court addresses such flaws in future cases.

Keywords: State immunity; employment claims; European Court of $\mathrm{Hu}-$ man Rights; right of access to a court; alternative means of redress

\section{Resumo}

Este artigo analisa a jurisprudência do Tribunal Europeu dos Direitos do Homem sobre a relação entre a imunidade do Estado e o direito dos funcionários estrangeiros de acesso a um tribunal, protegido ao abrigo do Artigo 6 da Convenção Europeia dos Direitos do Homem. Embora reconheça que a jurisprudência do Tribunal de Estrasburgo tem, em muitos aspectos, contribuído para fornecer aos funcionários de estados estrangeiros um acesso mais amplo aos tribunais dos estados receptores, o estudo sustenta que o tratamento do Tribunal de casos trabalhistas apresenta algumas falhas importantes. Nomeadamente, argumenta-se que (i) a avaliação do Tribunal das normas do direito consuetudinário internacional na área da imunidade estatal de processos trabalhistas é mal comprovada e pouco convincente; (ii) esta avaliação falha do costume teve um impacto negativo sobre o escopo do 
direito dos funcionários de acesso a um tribunal; e (iii) segundo a abordagem seguida pelo Tribunal de Estrasburgo, certas categorias de funcionários públicos podem ficar sem quaisquer meios judiciais de obter reparação. Parece crucial que o Tribunal trate dessas falhas em casos futuros.

Palavras-chave: Imunidade estatal; reclamações trabalhistas; Tribunal Europeu de Direitos Humanos; direito de acesso a um tribunal; meios alternativos de reparação

\section{Introduction}

One of the most controversial aspects of the jurisdictional immunity of foreign states concerns its relationship with the right of access to justice, i.e. the right of private individuals to have their case heard by a court. This right constitutes one of the basic components of the right to a fair trial, which is enshrined in major human rights instruments. For example, in Barbani Duarte, the Inter-American Court of Human Rights held that the right to a hearing under Article 8(1) of the American Convention on Human Rights (ACHR) encompasses a right to "access to the competent body to determine the right that is claimed, respecting due procedural guarantees (such as the presentation of arguments and the provision of evidence)". ${ }^{1}$ The right of access to justice is also held to be part of customary international law. ${ }^{2}$ State immunity, which is also an undisputed rule of customary international law, ${ }^{3}$ by contrast prohibits national courts from exercising jurisdiction over claims brought by private individuals against foreign states. Access to justice and immunity are thus in direct conflict with each other and it is necessary to devise legal criteria to reconcile them. ${ }^{4}$ Among the va-

\footnotetext{
1 AMERICAN COURT OF HUMAN RIGHTS. Barbani Duarte et al. v. Uruguay, 13 October 2011, Series C No. 234, para. 122.

2 FRANCIONI, F. The Rights of Access to Justice under Customary International Law, in: FRANCIONI, F. (ed.). Access to Justice as a Human Right. Oxford: Oxford University Press, 2007; SHELTON, D. Remedies in International Human Rights Law, 3rd edn. Oxford: Oxford University Press, 2015. p. 238.

3 INTERNATIONAL COURT OF JUSTICE. Jurisdictional Immunities of the State (Germany v. Italy: Greece intervening). Judgment, 2012, para. 56. Available at: https://www.icj-cij.org/public/files/caserelated/143/143-20120203-JUD-01-00-EN.pdf. Accessed on: 6 Mayo 2021.

${ }^{4}$ IOVANE, M. Conflicts Between State-Centred and Human-Centred International Norms. In: PISILLO MAZZESCHI, R., De Sena,
}

rious international courts and tribunals and human rights treaty bodies which have addressed this issue, ${ }^{5}$ by far the greatest amount of jurisprudence on this subject has been produced by the European Court of Human Rights (ECtHR; the Strasbourg Court). ${ }^{6}$

A substantial portion of the state immunity cases heard by the Strasbourg Court has originated from labour litigation with foreign states. ${ }^{7}$ In all such cases, the applicants were current, former or would-be employees of foreign states' establishments located in the territory of other states, such as embassies, consulates or trade offices. They attempted to sue the foreign state before the courts of the countries where such establishments were located, but their employment claims (relating, for example, to unpaid wages, social contributions, unlawful dismissals or workplace discrimination) were barred by state immunity. Against this backdrop, these individuals have turned to the ECtHR alleging that the forum state's refusal to adjudicate their claims on grounds of state immunity breached their right of access to a court provided under Article 6 (Right to fair trial) of the European Convention on Human Rights (ECHR). ${ }^{8}$ In response, the ECtHR has developed a rich case law on how to manage the tension between the employer states' entitlement to jurisdictional immunity and the need to ensure protection of the rights of employees. ${ }^{9}$

P. (ed.), Global Justice, Human Rights and the Modernization of International Law. Cham: Springer, 2018. p. 218.

5 On this point see, e.g., HUMAN RIGHTS COMMITTEE. General Comment No. 32: Article 14: Right to equality before courts and tribunals and to a fair trial, 23 August 2007, CCPR/C/GC/32, para. 18.

${ }^{6}$ See KLOTH, M. Immunities and the Right of Access to Court under Article 6 of the European Convention on Human Rights. Leiden - Boston: Nijhoff, 2010.

7 The greatest amount of domestic civil litigation involving foreign states concerns labour-related issues: see FOX, H.; WEBB, P. The Law of State Immunity. Third edition. Oxford: Oxford University Press, 2013. p. 440.

8 Pursuant to Art. 6(1) European Convention on Human Rights, 4.11.1950 (Rome), "In the determination of his civil rights and obligations [...], everyone is entitled to a fair and public hearing within a reasonable time by an independent and impartial tribunal established by law". This provision presupposes a right of access to a court: EUROPEAN COURT OF HUMAN RIGHTS (ECtHR). Golder v. United Kingdom, 21 February 1975, App. No. 4451/70, paras. 28-36.

9 On this tension see generally WEBB, P. The Immunity of States, Diplomats and International Organizations in Employment Disputes: The New Human Rights Dilemma? European Journal of International Law, v. 27, n. 3, 2016. 
This paper performs a critical analysis of the Strasbourg Court's jurisprudence on this peculiar category of state immunity litigation. In particular, as far as methodology is concerned, it intends to evaluate all the decisions of the ECtHR concerning state immunity in labour claims - as well as, where opportune, judicial decisions of national courts which relied on ECtHR precedents in light of the pertinent legal scholarship and to identify strengths and shortcomings of such decisions. After a concise account of the key features of the Court's approach and of its contribution to the enhancement of the judicial protection of labor rights (Section 2), this paper makes the argument that the Strasbourg Court's handling of labour cases has also given rise to serious problems and that the Court should consider remedying these flaws in future decisions. In particular, Section 3 criticises the conclusions reached by the ECtHR as to the status of customary international law in the area of state immunity from employment suits. Section 4 shows how this flawed assessment of custom has had a negative impact on the scope of the employees' right of access to a court. Finally, Section 5 argues that the Court paid insufficient attention to a problematic side-effect of its jurisprudence - i.e. that, where a grant of immunity is held to be compatible with Article 6 ECHR, it is possible that an employee may be left without any effective judicial means of obtaining redress.

\section{The Strasbourg Court's approach to state immunity in employment cases}

The Strasbourg Court's approach to state immunity in employment litigation should be analyzed within the framework of the ECtHR's general approach to state immunity. In fact, the Court is frequently confronted with cases brought by individuals who, having unsuccessfully attempted to sue a foreign state before the courts of a state party to the ECHR, claim that that state party breached their right of access to justice.

The ECtHR has developed a well-established set of principles on how to handle such cases. Limitations on the right of access to a court are considered admissible as long as they do not impair the very essence of the right, pursue legitimate aims and are proportionate to the aims pursued. ${ }^{10}$ The legitimacy prong of the test is unproblematic: the ECtHR has constantly reaffirmed that state immunity pursues the legitimate aim of "complying with international law to promote comity and good relations between States through the respect of another State's sovereignty". "What is instead decisive is the proportionality assessment. In this respect, the Court's approach is to consider a grant of immunity to be a proportionate limitation on Article 6 ECHR if the forum state was required to grant immunity under general international law. ${ }^{12}$ This may be seen as a prime example of harmonious interpretation, that is the principle whereby the Convention "should so far as possible be interpreted in harmony with other rules of international law": ${ }^{13}$ the rationale of this approach is to avoid conflict with the other international obligations binding on the states of the Council of Europe. ${ }^{14}$ It should be noted that this approach is not unique to the ECtHR. Most notably, the Human Rights Committee has similarly held that the right to a fair trial under Article 14 of the International Covenant on Civil and Political Rights (ICCPR) is not breached by restrictions "based on exceptions from jurisdiction deriving from international law such, for example, as immunities". ${ }^{15}$

The Strasbourg Court had its first chance to apply these principles to the context of labour claims in the 2001 Fogarty v. United Kingdom judgment. ${ }^{16}$ The applicant was employed as an administrative assistant at the embassy of the United States in London from 1993 to her dismissal in 1995. She sued before the English courts for discriminatory dismissal and was awarded compensation; no issue of immunity arose during the proceedings because the United States defended itself on the merits. After two unsuccessful applications for secretarial jobs at the Embassy, Fogarty filed a new discrimination suit before the

\footnotetext{
${ }_{10}$ See e.g. ECtHR. Naït-Litman v. Switzerland, 15 March 2018, App. No. 51357/07, paras. 114-5.

11 ECtHR. Al-Adsani v. United Kingdom, 21 November 2001, (GC), App. No. 35763/97, para. 54.

12 ECtHR. Al-Adsani v. United Kingdom, 21 November 2001, (GC), App. No. 35763/97, para. 56.

13 ECtHR. Al-Adsani v. United Kingdom, 21 November 2001, (GC), App. No. 35763/97, para. 55.

${ }_{14}$ BONAFÈ, B.I. The ECHR and the Immunities Provided by International Law. Italian Yearbook of International Law, v. 20, 2010, p. 63-66.

15 HUMAN RIGHTS COMMITTEE. General Comment No. 32: Article 14: Right to equality before courts and tribunals and to a fair trial, 23 August 2007, CCPR/C/GC/32, para. 18.

16 ECtHR, Fogarty v. United Kingdom, 21 November 2001, (GC), App. No. 37112/97.
} 
English courts claiming that the United States' failure to re-employ her was a consequence of her previous sex discrimination claim. At this stage, the United States claimed immunity from jurisdiction pursuant to the State Immunity Act (SIA) 1978, the United Kingdom's domestic legislation on foreign state immunity. Although section 4 of the SIA enumerates cases where a foreign state is not entitled to immunity in lawsuits relating to contracts of employment, ${ }^{17}$ section 16 stipulates that such grounds of non-immunity do not apply to employment at diplomatic and consular missions, thus effectively bestowing absolute immunity from labour claims upon foreign embassies and consulates. ${ }^{18}$ Because section 16 left her without any remedy in the law of the United Kingdom, Fogarty applied to the ECtHR claiming that her right of access to a court had been breached.

The Grand Chamber ruled in favour of the respondent state. The refusal by the United Kingdom to exercise jurisdiction over Fogarty's claim was considered to be compatible with the content of general international law and thus to constitute a proportionate restriction on the applicant's right of access to justice. More specifically, the Court noted that international practice was divided as regards whether states enjoyed immunity from claims by personnel at diplomatic missions: the fact that the United Kingdom was "not alone in holding that immunity attaches to suits by employees at diplomatic missions" meant, in the Court's view, that its practice did not "fall $[\ldots]$ outside any currently accepted international standards". ${ }^{19}$ The ECtHR also gave weight to the fact that the applicant's proceedings before the English courts concerned her recruitment process: as the Court put it, "[q]uestions relating to the recruitment of staff to

\footnotetext{
${ }^{17}$ Most notably, it provides that a state is entitled to immunity if "(a) at the time when the proceedings are brought the individual is a national of the State concerned; or (b) at the time when the contract was made the individual was neither a national of the United Kingdom nor habitually resident there; or (c) the parties to the contract have otherwise agreed in writing". This provision largely reproduces the content of Art. 5 of the European Convention on State Immunity, 16.5.1972 (Basel).

18 Note however that, in SUPREME COURT (UK), Benkharbouche v. Secretary of State for Foreign and Commonwealth Affairs and Secretary of State for Foreign and Commonwealth Affairs and Libya v. Janah, 18 October 2017, [2017] UKSC 62, s. 16 was declared incompatible with Art. 6 European Convention on Human Rights, 4.11 .1950 (Rome) insofar as it bars claims by low-level employees. As will be seen below, this case may be seen as an outgrowth of the ECtHR's jurisprudence on the subject.

19 ECtHR. Fogarty v. United Kingdom, 21 November 2001, (GC), App. No. 37112/97, para. 37.
}

missions and embassies may by their very nature involve sensitive and confidential issues", and the Court was not aware of any state practice where jurisdiction over such claims had been exercised. ${ }^{20}$ It should be highlighted that the Court in Fogarty showed considerable self-restraint in the identification of relevant norms of customary international law: it only established whether the United Kingdom was allowed to grant immunity over the applicant's specific claims, but refrained from discussing the status of custom outside of what was strictly necessary to rule on the case. Hence, this judgment offered little guidance on how future cases on state immunity and employment would be decided by the ECtHR.

By contrast, in the subsequent case of Cudak v. Lithuania the ECtHR proved more liberal in its identification of customary norms and, in so doing, laid down more clear guidelines for future decisions. ${ }^{21}$ In order to determine the content of customary law for the purposes of the proportionality assessment, the Court turned to the text of the 2004 United Nations Convention on State Immunity (UNCSI) 22 - the not-yet-into-force outcome of the works of the International Law Commission (ILC) on the topic of jurisdictional immunities of states $^{23}$ - and held that its Article 11, on contracts of employment, constitutes in its entirety a codification of international custom. ${ }^{24}$ This provision sets forth a general rule of non-immunity in labour disputes (paragraph 1) followed by an exhaustive list of exceptions where immunity applies (paragraph 2). The grounds of immunity are: (a) the employee performs "particular functions in the exercise of governmental authority"; (b) the employee is a diplomatic or consular agent or "any other person enjoying diplomatic immunity"; (c) the proceedings concern recruitment, renewal of employment or reinstatement; (d) the proceedings concern dismissal and the foreign state declares that they would

20 ECtHR. Fogarty v. United Kingdom, 21 November 2001, (GC), App. No. 37112/97, para. 38.

${ }^{21}$ ECtHR. Cudak v. Lithuania, 23 March 2010, (GC), App. No. $15869 / 02$.

22 United Nations Convention on Jurisdictional Immunities of States and Their Property, 2.12.2004 (New York).

23 Pursuant to its Art. 30, the United Nations Convention on Jurisdictional Immunities of States and Their Property, 2.12.2004 (New York) will enter into force upon deposit of the thirtieth ratification. As of Mayo 2021 it has been ratified by 22 states: see https://treaties. un.org $/$ Pages $/$ ViewDetails.aspx?src $=$ TREATY\&mtdsg_no $=$ III$13 \&$ chapter $=3 \&$ clang=_en. Accessed on: 6 Mayo 2021.

${ }^{24}$ ECtHR. Cudak v. Lithuania, 23 March 2010, (GC), App. No. 15869/02, para. 67. 
interfere with its security interests; (e) the employee is a national of the employer state not residing in the state of the forum; and (f) the parties have derogated in writing from the forum state's jurisdiction. Simply put, Cudak turned this provision into a standard of compliance of grants of state immunity in employment matters: an immunity broader than required by Article 11 amounts to a breach of Article 6 ECHR.

In Cudak the application of Article 11 led the Court to rule in favour of the applicant, a former secretary at the Polish embassy in Vilnius. The Lithuanian Supreme Court had upheld immunity over her unlawful dismissal claim against Poland, reasoning that her employment "facilitated, to a certain degree, the exercise by [...] Poland of its sovereign functions" and thus fell within the category of acta jure imperii. ${ }^{25}$ The ECtHR, however, held that none of the Article 11 immunity grounds applied to this case, most notably because the applicant did not perform any "particular functions in the exercise of governmental authority", her claims (unlike Fogarty's) did not concern recruitment and she was a national of Lithuania. ${ }^{26}$ In all subsequent cases on the subject the ECtHR has followed the same script, regardless of whether a respondent state had signed or ratified the UNCSI. In the vast majority of such judgments the Court has found immunity to exceed the limits of Article 11 and thus to be a disproportionate compression of the applicant's right of access to a court. ${ }^{27}$ Only in one case has the Court ruled otherwise on the grounds that the applicant was a national of the employer state not residing in the forum state, a situation covered by Article 11, paragraph 2(e), UNCSI. ${ }^{28}$

There is no doubt that the Court's jurisprudence has contributed in significant respects to enhancing the judicial protection of foreign states' employees. ${ }^{29}$

\footnotetext{
25 Quoted in ECtHR, Cudak v. Lithuania, 23 March 2010, (GC), App. No. 15869/02, para. 18.

${ }^{26}$ ECtHR. Cudak v. Lithuania, 23 March 2010, (GC), App. No. 15869/02, paras. 69-72.

27 ECtHR. Guadagnino v. Italy and France, 18 January 2011, App. No. 2555/03; ECtHR. Sabeh El Leil v. France, 29 June 2011, App. No. 34869/05; ECtHR. Wallishauser v. Austria, 17 July 2012, App. No. 156/04, para. 71 (in obiter dictum); ECtHR. Radunovic and Others $v$. Montenegro, 25 October 2016, App. Nos. 45197/13, 53000/13 and 73404/13; ECtHR. Naku v. Lithuania and Sweden, 8 November 2016, App. No. 26126/07.

28 ECtHR. Ndayegamiye-Mporamazina v. Switzerland, 5 February 2019, App. No. 16874/12.

${ }^{29}$ For largely positive appraisals of the ECtHR's approach see GARNETT, R. State and Diplomatic Immunity and Employment
}

Its approach creates strong incentive for states to cease applying absolute or overly broad immunity, which is, regrettably, still relatively widespread in the area of employment litigation also among the members of the Council of Europe: $:^{30}$ if a state does not align itself to the ECtHR's approach, there is a likelihood that it will be condemned in Strasbourg. An example of the influence exercised by the ECtHR's case law over national approaches is provided by the landmark Benkharbouche judgment, where the Supreme Court of the United Kingdom held that the aforementioned section 16 of the UK SIA was incompatible with the ECHR insofar as it granted immunity over all claims filed by employees at diplomatic and consular missions regardless of their functions. The Supreme Court found that barring claims from members of the service staff of an embassy was not required under general international law. ${ }^{31}$ The ECtHR's case law has also exercised a direct influence over the Italian and French Courts of Cassation, both of which have applied Article 11 UNCSI qua codification of customary international law. ${ }^{32}$

Another notable aspect of the ECtHR's case law is that the Court has affirmed that the immunity grounds enshrined in Article 11 "must be strictly interpreted", 33 so that, in case of doubt, the reading more favourable to the applicant employee should be preferred. This precept is particularly important when it comes to the interpretation of paragraph 2(a), which bars claims filed by employees tasked with "particular functions in the exercise of governmental authority". Neither the text of the UNCSI nor the travaux préparatoires provide conclusive indications as to which employees are covered by this provision..$^{34}$ This is problematic because most state

Rights: European Law to the Rescue? International \& Comparative Law Quarterly, v. 64, 2015; NIGRO, R. Immunità degli Stati e diritto di accesso al giudice: un nuovo approccio nel diritto internazionale? Rivista di diritto internazionale, v. 96, n. 3, 2013.

${ }^{30}$ See for example HIGH COURT OF CASSATION AND JUSTICE (Romania), SDG v. Canada and Prosecutor General (joining), 1 April 2003, No. 1292, ILDC 1024 (RO 2003).

31 SUPREME COURT (UK), Benkharbouche v. Secretary of State for Foreign and Commonwealth Affairs and Secretary of State for Foreign and Commonwealth Affairs and Libya v. Janah, 18 October 2017, [2017] UKSC 62.

32 CORTE DI CASSAZIONE (Italy), Embassy of Spain to the Holy See v. De la Grana Gonzales, 11 March 2014, No. 9034, ILDC 2436 (IT 2014); COUR DE CASSATION (France), B v. Republic of Ghana, 27 November 2019, No. 18-13790, ILDC 3070 (FR 2019).

33 ECtHR. Sabeh El Leil v. France, 29 June 2011, App. No. 34869/05, para. 66.

${ }^{34}$ FOAKES, J.; O'KEEFE, R. Article 11, in: O'KEEFE, R.; TAMS, C. (eds.), The United Nations Convention on Jurisdictional Immunities of 
employees may be regarded as performing tasks at least to some extent connected to their employer's governmental authority. The ECtHR, by contrast, requires that the duties of an employee must be "objectively" linked to a state's exercise of its sovereign powers ${ }^{35}$ and places the burden of proving the existence of this link upon the state. ${ }^{36}$ Relatively high-ranking employees have been found by the Court not to fall within the scope of letter (a), including for instance an embassy's head accoun$\operatorname{tant}^{37}$ or an embassy's protocol specialist and translator. ${ }^{38}$

\section{The codificatory character of Article 11 UN Convention on State Immunity: a problematic assumption}

Other aspects of the Strasbourg Court's case law on state immunity in employment matters, however, appear problematic. This is the case, first of all, with the assumption that Article 11 UNCSI constitutes a verbatim codification of general international law.

It is well-known that a norm of customary international law may be said to have come into existence in the presence of a general practice of states accompanied by a belief that this practice is required by law (opinio juris). ${ }^{39}$ The ascertainment of a customary norm would in principle require proof of both such cons-

States and Their Property: A Commentary. Oxford: Oxford University Press, 2013. p. 208.

35 ECtHR, Cudak v. Lithuania, 23 March 2010, (GC), App. No. 15869/02, para. 70 .

${ }^{36}$ ECtHR. Guadagnino v. Italy and France, 18 January 2011, App. No. 2555/03, para. 72.

37 ECtHR. Sabeh El Leil v. France, 29 June 2011, App. No. 34869/05, para. 62.

38 ECtHR. Radunovic and Others v. Montenegro, 25 October 2016, App. Nos. 45197/13, 53000/13 and 73404/13.

39 Art. 38(1)(b) of INTERNATIONAL COURT OF JUSTICE. Statute of the International Court of Justice. Available at: https://www. icj-cij.org/en/statute. Accessed on: 6 Mayo 2021. For restatements in the ICJ case law see, inter alia, INTERNATIONAL COURT OF JUSTICE. North Sea Continental Shelf Cases (Federal Republic of Germany/Denmark; Federal Republic of Germany/Netherlands). Judgment, 1969, para. 77. Available at: https://www.icj-cij.org/public/ files/case-related/52/052-19690220-JUD-01-00-EN.pdf. Accessed on: 6 Mayo 2021. INTERNATIONAL COURT OF JUSTICE. Military and Paramilitary Activities in and against Nicaragua (Nicaragua v. United States of America). Merits, Judgment, 1986, para. 184. Available at: https://www.icj-cij.org/public/files/case-related/70/07019860627-JUD-01-00-EN.pdf. Accessed on: 6 Mayo 2021. titutive elements, ${ }^{40}$ and this proof should be obtained inductively by looking at the practice of states. ${ }^{41}$ In $J u$ risdictional Immunities, the International Court of Justice (ICJ) found that, in the area of state immunity, "the most pertinent State practice" may be found in national judicial decisions. ${ }^{42}$ Other sources of relevant state practice are national legislation concerning immunities, claims to immunity advanced by impleaded states before foreign courts and the opinions voiced by states in course of the ILC work on state immunity. ${ }^{43}$ Opinio juris, for its part, may be drawn from "the assertion by States claiming immunity that international law accords them a right to such immunity $[. .] ;.[. .$.$] the acknowledgment,$ by States granting immunity, that international law imposes upon them an obligation to do so; and [...] the assertion by States in other cases of a right to exercise jurisdiction over foreign States". ${ }^{4}$

In Cudak, however, the ECtHR attempted no survey of state practice. The only state practice actually examined in some detail by the Court was the legislative and judicial practice of Lithuania. ${ }^{45}$ Instead, the main argument invoked by the Court in support of the codificatory character of Article 11 was a passage of the ILC's commentary to the 1991 Draft Articles on State Immunity where it was stated that Article 11 "appear[s] to be consistent with the emerging trend in the recent legislative and treaty practice of a growing number of States". ${ }^{46}$ The ECtHR interpreted this passage in the

40 INTERNATIONAL LAW COMMISSION, Draft conclusions on identification of customary international law, with commentaries. 2018. Yearbook of the International Law Commission, v. II (Two). Conclusion 2.

${ }^{41}$ SUCHARITKUL, S. Developments and Prospects of the Doctrine of State Immunity: Some Aspects of Codification and Progressive Development. Netherlands International Law Review, v. 29, p. 259, 1982.

${ }^{42}$ INTERNATIONAL COURT OF JUSTICE. Jurisdictional Immunities of the State (Germany v. Italy: Greece intervening). Judgment, 2012, para. 73. Available at: https://www.icj-cij.org/public/files/ case-related/143/143-20120203-JUD-01-00-EN.pdf. Accessed on: 6 Mayo 2021.

${ }^{43}$ INTERNATIONAL COURT OF JUSTICE. Jurisdictional Immunities of the State (Germany v. Italy: Greece intervening). Judgment, 2012, para. 55. Available at: https://www.icj-cij.org/public/files/ case-related/143/143-20120203-JUD-01-00-EN.pdf. Accessed on: 6 Mayo 2021.

${ }^{44}$ INTERNATIONAL COURT OF JUSTICE. Jurisdictional Immunities of the State (Germany v. Italy: Greece intervening). Judgment, 2012, para. 55. Available at: https://www.icj-cij.org/public/files/ case-related/143/143-20120203-JUD-01-00-EN.pdf. Accessed on: 6 Mayo 2021.

45 ECtHR, Cudak v. Lithuania, 23 March 2010, (GC), App. No. 15869/02, paras. 19-24.

46 INTERNATIONAL LAW COMMISSION, Draft Articles on Ju- 
sense that that article was meant to codify the existing practice of states. ${ }^{47}$ The Court also affirmed that what the Commission said with regard to the 1991 Draft "must also hold true for the 2004 United Nations Convention". 48

The ECtHR is far from isolated among international courts in its reliance on ILC works or codification conventions for the ascertainment of international custom. ${ }^{49}$ On multiple occasions, the ICJ has considered provisions of such instruments to embody customary norms without conducting an autonomous evaluation of the practice of states. Just to make a few notable examples, in Oil Platforms the ICJ reached this conclusion with regard to the rules of treaty interpretation of Article 31 of the 1969 Vienna Convention on the Law of Treaties, ${ }^{50}$ and in Armed Activities in respect to the rules of attribution of conduct contained in Articles 4, 5 and 8 of the Articles on the Responsibility of States for Internationally Wrongful Acts. ${ }^{51}$ This practice may be justified as a way for a court of "outsourcing" the ascertainment of customary law to the ILC, which is institutionally better positioned than a court to perform extensive surveys of state practice. ${ }^{52}$ However, it is only possible to speak of "outsourcing" if the ILC did conduct such a survey of state practice in the first place and if it did intend a certain provision to be reflective of such practice. ${ }^{53}$ There can be no guarantee

risdictional Immunities of States and Their Property, with commentaries. 1991. Yearbook of the International Law Commission, v. II (Two). para. 14.

47 ECtHR, Cudak v. Lithuania, 23 March 2010, (GC), App. No. 15869/02, paras. 66-67.

48 ECtHR, Cudak v. Lithuania, 23 March 2010, (GC), App. No. 15869/02, para. 66.

49 IOVANE, M. L'influence de la multiplication des juridictions internationales sur l'application du droit international. Recueil des Cours: collected courses of The Hague Academy of International Law. Kluwer Law International, Hague, v. 383, 2017. p. 394-397.

${ }^{50}$ INTERNATIONAL COURT OF JUSTICE. Oil Platforms (Islamic Republic of Iran v. United States of America), Preliminary Objection, Judgment, 1996, para. 23. Available at: https://www.icj-cij.org/ public/files/case-related/90/090-19961212-JUD-01-00-EN.pdf. Accessed on: 6 Mayo 2021.

${ }^{51}$ INTERNATIONAL COURT OF JUSTICE. Armed Activities on the Territory of the Congo (Democratic Republic of the Congo v. Uganda), Judgment, 2005, para. 160. Available at: https://www.icj-cij.org/ public/files/case-related/116/116-20051219-JUD-01-00-EN.pdf. Accessed on: 6 Mayo 2021.

${ }^{52}$ LUSA BORDIN, F. Reflections of Customary International Law: The Authority of Codification Conventions and ILC Draft Articles in International Law. International \& Comparative Law Quarterly, v. 63, 2014, p. 549-558.

53 See WOOD, M. Third Report on identification of customary international law. UN Doc. A/CN.4/682, 27 March 2015, para. 65. that everything that comes out of the works of the ILC meets similar standards. The Commission's institutional goals comprise not only the codification of customary law but also its progressive development ${ }^{54}$ - meaning that the ILC might intend a certain provision not to reflect state practice if this contributes to the progress of general international law. Moreover, the states may be heavily involved in the drafting of a convention's provision, which may thus be reflective less of existing state practice and more of political compromise.

In light of the above, what is most problematic about Cudak is not the ECtHR's reliance on ILC works per se, but the fact that - contrary to what the Court opined - the ILC has never remotely suggested that Article 11 UNCSI was intended to reflect existing practice of states in its entirety. In fact, this provision was one of the most hotly debated over the course of the ILC work on the topic of state immunity. ${ }^{55}$ Special Rapporteur Sucharitkul wrote in his 1983 First Report that state practice on the subject of state immunity from employment claims was scarce and that the limited practice available at the time presented a "startling number of inconsistencies and contradictions". ${ }^{56}$ There can thus be no doubt that Sucharitkul's Draft Article 13 - the precursor of Article 11 UNCSI - was for the most part an exercise in progressive development. ${ }^{57}$ The original contours of this draft broadly reflected the provision on contracts of employment (Article 5) of the earlier European Convention on State Immunity, pursuant to which immunity should apply only in two cases: where the employee is (i) a national of the employer state when the proceedings are brought, or (ii) neither a national

54 INTERNATIONAL LAW COMMISSION. Statute of the International Law Commission. Available at: https://legal.un.org/ilc/texts/instruments/english/statute/statute.pdf. Accessed on: 6 Mayo 2021. See Art. 1(1): "The International Law Commission shall have for its object the promotion of the progressive development of international law and its codification". See also Art. 13(1)(a) of the Charter of the United Nations, 26.6.1945 (San Francisco), pursuant to which the General Assembly "shall initiate studies and make recommendations for the purpose of $[\ldots]$ encouraging the progressive development of international law and its codification".

55 FOAKES, J.; O'KEEFE, R. Article 11. In: O'KEEFE, R.; TAMS, C. (ed.). The United Nations Convention on Jurisdictional Immunities of States and Their Property: A Commentary. Oxford: Oxford University Press, 2013. p. 189.

56 SUCHARITKUL, S. Fifth Report on Jurisdictional Immunities of States and Their Property. 1983. Yearbook of the International Law Commission, v. II (One). para. 39.

57 The text of the Draft Article is in SUCHARITKUL, S. Fifth Report on Jurisdictional Immunities of States and Their Property. 1983. Yearbook of the International Law Commission, v. II (One). para. 62. 
nor a resident of the state of the forum at the time of recruitment. ${ }^{58}$ Sucharitkul's only original addition was a provision granting immunity if the claim concerned the recruitment or dismissal of an employee. ${ }^{59}$ In both cases, the state practice cited in support of such provisions was limited: it boiled down to a handful of state immunity instruments adopted by countries of common law (themselves modeled after the Article 5 ECSI footprint, as in the case of the UK SIA) and to Italian and French judicial decisions. ${ }^{60}$

The text of then-Article 13 was thoroughly altered during the following discussions and drafting process with the addition of new grounds of immunity: the 1991 Draft Articles, most notably, included a provision whereby claims brought by employees performing tasks de jure imperii should be covered by immunity - a provision reflected, with some textual differences, in Article 11(2)(a) UNCSI. ${ }^{61}$ But the cited state practice was again limited: in support of the newly-added letter (a), for example, the Draft Articles only mentioned three decisions of the Italian Court of Cassation. ${ }^{62}$ After 1991, the topic of contracts of employment was one of several outstanding substantive issues submitted to the attention of an ILC Working Group and of an Ad Hoc Committee created by the General Assembly. ${ }^{63}$ This produced other changes to the provision. For example, the relevance of the nationality and residence of the employee was significantly diminished when compared to the 1991 Draft Articles, whose provisions on the point still closely resembled those of the ECSI. In the

58 SUCHARITKUL, S. Fifth Report on Jurisdictional Immunities of States and Their Property. 1983. Yearbook of the International Law Commission, v. II (One). Art. 13(2)(b) and (c).

59 SUCHARITKUL, S. Fifth Report on Jurisdictional Immunities of States and Their Property. 1983. Yearbook of the International Law Commission, v. II (One). Art. 13(2)(a).

60 SUCHARITKUL, S. Fifth Report on Jurisdictional Immunities of States and Their Property. 1983. Yearbook of the International Law Commission, v. II (One). paras. 42-54.

${ }^{61}$ See Draft Article 11(2)(a), pursuant to which immunity applies to claims by employees "recruited to perform functions closely related to the exercise of governmental authority".

${ }^{62}$ INTERNATIONAL LAW COMMISSION, Draft Articles on Jurisdictional Immunities of States and Their Property, with commentaries. 1991. Yearbook of the International Law Commission, v. II (Two). p. 43, para. 10.

${ }^{63}$ On the drafting of the United Nations Convention on Jurisdictional Immunities of States and Their Property, 2.12.2004 (New York) see HAFNER, G. Historical Background of the Convention. In: O'KEEFE, R.; TAMS, C. (ed.). The United Nations Convention on Jurisdictional Immunities of States and Their Property: A Commentary. Oxford: Oxford University Press, 2013.
UNCSI's final text, only nationals of the employer state not residing in the forum state at the time of commencement of the proceedings are barred from suing their employer. ${ }^{64}$

In sum, all Article 11's drafting process reflected difficult compromises and considerable second-guessing. ${ }^{65}$ Looking back at the passage by the ILC quoted by the ECtHR in Cudak, it is clear that the Commission was much more cautious than the Court suggested: not only did it refer to emerging rather than existing state practice, but it also merely pointed to an increasing (though unspecified) number of states. This is a far cry from saying that state practice had already reached the critical threshold for the existence of custom. And indeed, when the Commission actually believed a certain portion of Draft Article 11 to be reflective of existing state practice, it did so expressly: this was the case (only) with Draft Article 11(2)(b), barring jurisdiction if "the subject of the proceeding is the recruitment, renewal of employment or reinstatement of an individual". This provision was described as "designed to confirm the existing practice of states" ${ }^{66}$ Moreover, even assuming that the Commission really meant to say that Draft Article 11 was a codification of custom, such an assessment may hardly be extended to Article 11 UNCSI, considering that the two provisions differ in significant respects.

\section{The drawbacks of the Strasbourg Court's use of Article 11: adverse effects on the rights of employees}

The previous section has argued that the ECtHR's exclusive reliance on ILC works may be considered, in the case of Article 11 UNCSI, as a flawed method of custom ascertainment. But this criticism does not con${ }^{64}$ Cf. Draft Article 11(2)(c) and (d) with Article 11(2)(e) United Na-
tions Convention on Jurisdictional Immunities of States and Their Property,
2.12.2004 (New York).
65 PAVONI, R. The Myth of the Customary Nature of the United
Nations Convention on State Immunity: Does the End Justify the
Means? In: VAN AAKEN, A.; MOTOC, I. (ed.), European Conven-
tion on Human Rights and General International Law. Oxford: Oxford
University Press, 2018. p. 277 .
66 INTERNATIONAL LAW COMMISSION, Draft Articles on Ju-
risdictional Immunities of States and Their Property, with commentaries. 1991.
Yearbook of the International Law Commission, v. II (Two). p. 43, para.
10. 
cern merely the method employed by the ECtHR: in fact, the Court's use of Article 11 may have negative repercussions on the scope of the employees' right of access to a court. The reason is that several provisions of Article 11 UNCSI recognise to employer states an immunity broader than what is arguably required by customary international law. ${ }^{67}$ In such cases, by applying Article 11, a grant of immunity would not be treated by the Strasbourg Court as a violation of Article 6 ECHR; however, a more detailed assessment of state practice would most likely lead the Court to the conclusion that such a grant of immunity is impermissible.

The pitfalls of the ECtHR's use of Article 11 may be exemplified by analyzing the 2019 judgment in the Ndayegamiye case. ${ }^{68}$ Since 1993 the applicant, a national of Burundi, had been living with her family in a French village bordering Switzerland. In 1995 she was hired by Burundi's Permanent Mission to the United Nations in Geneva. Being the only administrative employee of the Mission, she performed a variety of tasks ranging from secretarial and accounting to the issuing of passports and visas. In 2007 her contract was not renewed and she sued Burundi before the Swiss courts for unlawful dismissal. At last instance, the Federal Tribunal held that the Swiss courts did not have jurisdiction over her claims. The Tribunal's main argument was that the tasks the employee performed were closely intertwined with Burundi's exercise of its sovereign powers. ${ }^{69}$ Following the Federal Tribunal's decision, the applicant sued Switzerland before the Strasbourg Court. The ECtHR, however, ruled that the applicant's right of access to justice had not been disproportionately limited by the decisions of the Swiss courts. The reason was that, since the applicant was a Burundian national residing in France, her claim fell squarely within the grounds of immunity set forth by Article 11(2)(e) UNCSI, where-

\footnotetext{
${ }^{67}$ KÖHLER, U. Contracts of Employment under the UN Convention on Jurisdictional Immunities of States and Their Property. Austrian Review of International and European Law, v. 9, 2004. p. 215; DE VITTOR, F. Recenti sviluppi in tema di immunità degli Stati dalla giurisdizione: la Convenzione di New York del 2 dicembre 2004. In: LANCIOTTI, A.; TANZI, A. (ed.), Le immunità nel diritto internazionale. Temi scelti. Torino: Giappichelli, 2007. p. 180. On this point see further ROSSI, P. Controversie di lavoro e immunità degli Stati esteri: tra codificazione e sviluppo del diritto consuetudinario. Rivista di diritto internazionale, v. 102, n. 1, 2019.

68 ECtHR. Ndayegamiye-Mporamazina v. Switzerland, 5 February 2019, App. No. 16874/12.

${ }^{69}$ Quoted in ECtHR. Ndayegamiye-Mporamazina v. Switzerland, 5 February 2019, App. No. 16874/12, para. 20.
}

by immunity applies if "the employee is a national of the employer State at the time when the proceeding is instituted, unless this person has the permanent residence in the State of the forum". ${ }^{70}$ Considering that immunity was found permissible on other grounds, the Court did not consider it necessary to rule on whether the applicant's tasks were covered by Article 11(2)(a). ${ }^{71}$

Still, it is far from certain that customary international law actually prohibits to exercise jurisdiction over employment claims brought by nationals of the employer state not residing in the state of the forum. In this respect, it is important to highlight that a claim is only barred by state immunity if the prohibition to exercise jurisdiction over said claim finds support in the vast majority of state practice and opinio juris. Even though it is sometimes asserted that state immunity is the default rule, so that any exception should be established as a separate rule of customary law, ${ }^{72}$ it is actually immunity that is an exception to the underlying territorial jurisdiction of the forum state. Because immunity is a rule barring the exercise of domestic jurisdiction, it is necessary to prove that the prohibition exists, not otherwise. $^{73}$ It is true that, in the works of the ILC and in the UNCSI, immunity is treated as the general rule and areas of non-immunity are laid down in an exhaustive list of exceptions $;{ }^{74}$ however, as Special Rapporteur Sucharitkul wrote, this was merely a drafting technique which the ILC intended to be "without prejudice to the controversial question as to whether immunity is a general rule from which may be carved certain exceptions, or immunity constitutes a set of exceptional circumstances which have to be established in each case". ${ }^{75}$

\footnotetext{
${ }^{70}$ ECtHR. Ndayegamiye-Mporamazina v. Switzerland, 5 February 2019, App. No. 16874/12, paras. 62-63.

${ }^{71}$ ECtHR. Ndayegamiye-Mporamazina v. Switzerland, 5 February 2019, App. No. 16874/12, para. 65.

${ }_{72}$ YANG, X. State Immunity in International Law. Cambridge: Cambridge University Press, 2012. p. 37-38.

73 In favour of territorial jurisdiction being the default rule and immunity being the exception see, among others, HIGGINS, R., Certain Unresolved Aspects of the Law of State Immunity. Netherlands International Law Review, v. 29, p. 265-276, 1982. p. 271; SINCLAIR, I. The Law of Sovereign Immunity: Recent Developments. Recueil des Cours: collected courses of The Hague Academy of International Law. Kluwer Law International, Hague, v. 176, 1980. p. 215.

74 United Nations Convention on Jurisdictional Immunities of States and Their Property, 2.12.2004 (New York), Part III: "Proceedings in which State immunity cannot be invoked".

75 SUCHARITKUL, S. Developments and Prospects of the Doctrine of State Immunity: Some Aspects of Codification and Progressive Development. Netherlands International Law Review, v. 29, p. 262, 1982.
} 
Against this backdrop, and following the principles on custom ascertainment referred to in the previous Section, in order to acquire a customary status a rule barring jurisdiction in cases to which Article 11(2)(e) UNCSI applies should find widespread adherence in national legislative and judicial practice. National courts should be expected to distinguish the treatment of citizens of the employer state according to their residency status; in cases where jurisdiction is exercised over claims by nationals of the employer state not residing in the state of the forum, one should expect the employer states to protest a breach of customary international law.

Yet, there is hardly any evidence of all this. In a significant number of countries, jurisdiction over claims by nationals of the employer state is routinely exercised without any discussion of their residency status. For instance, the Austrian Supreme Court upheld its jurisdiction over a lawsuit filed by a French national dismissed by the French consulate in Innsbruck. ${ }^{76}$ In fact, many courts do not even mention the nationality and the residence of the employee among the relevant factors for immunity determinations and base their decisions exclusively on other criteria, e.g. the tasks performed by the employee or the subject-matter of the claim (e.g. distinguishing between claims for reinstatement and claims for compensation). ${ }^{77}$ The Labour Court of Brussels expressly rejected any nationality-based distinction between employees of foreign states, reasoning that " $[\mathrm{t}]$ he nationality of the employee has no bearing on the laws applicable to contracts of employment executed in Belgium". ${ }^{78}$ Even in countries where the nationality and residence of the employee are considered to be relevant factors for delimiting immunity in employment claims, the outcomes reached by the courts do not necessarily mirror the content of Article 11(2)(e). For example, the UK SIA, while generally reproducing the content of Article 5 ECSI as regards the relevance of nationality and residence, lays down more favourable rules for employees of foreign states' commercial establishments: these are only prevented from suing if they were permanent residents of the employer state when the

\footnotetext{
${ }^{76}$ SUPREME COURT (Austria), French Consular Employee Claim Case, 14 June 1989, Case No. 9 Ob A 170/89, 86 ILR 583.

${ }^{77}$ YANG, X. State Immunity in International Law. Cambridge: Cambridge University Press, 2012. p. 162, with many references to case law.

78 LABOUR COURT OF BRUSSELS (Belgium), Kingdom of Morocco v. DR, 6 November 1989, 115 ILR 421. p. 422.
}

contract was made, regardless of nationality. ${ }^{79}$ Against this backdrop, a reasonable argument may be made that what Article 11(2)(e) provides has not reached the status of customary international law. Had the ECtHR performed even a cursory examination of state practice in the Ndayegamiye case, it is highly possible that it would have ruled in favour of the applicant.

The previous discussion suggests that it would be appropriate for the ECtHR to perform some survey of state practice before applying the relevant provisions of Article 11 in future cases. Should the Court do so, it is likely that it would refrain from applying several of the Article 11's grounds of immunity on account of their difference from customary international law. It would be of course impossible for this paper to analyze whether each provision of Article 11 finds adequate support in existing state practice. However, one may point to another example of a provision of Article 11 which is most certainly not reflective of customary international law. This is Article 11(2)(b)(iv), pursuant to which immunity applies to employment claims by "any [...] person enjoying diplomatic immunity".

On its face, this provision seems to partially contradict Article 11(2)(a). This latter provision, as seen above, only covers claims by employees performing "particular functions" de jure imperii, which reasonably does not include employees performing low-level functions: think, for example, of members of the service staff of an embassy such as cleaners, janitors and the like. However, if one takes sub-paragraph (iv) literally, this provision would re-introduce immunity for labour claims by large portions of the service staff. This is because, according to the Vienna Convention on Diplomatic Relations, all members of the staff of an embassy who are not nationals or permanent residents of the receiving state enjoy - no matter how lowly their level - immunity from civil jurisdiction for acts performed in an official capacity. ${ }^{80}$ A receiving state may also unilaterally grant privileges and immunities to any other member of the mission. ${ }^{81}$

Legal scholarship is divided over the meaning of sub-paragraph (iv). To some, the literal interpretation should be rejected because it finds no support whatsoe-

\footnotetext{
79 S. 4(3) State Immunity Act 1978 (UK). 80 Vienna Convention on Diplomatic Relations, 18.4.1961 (Vienna), Art. 37.

81 Vienna Convention on Diplomatic Relations, 18.4.1961 (Vienna), Art. 38(2).
} 
ver in the travaux. According to this restrictive view, this provision should be construed as referring to "miscellaneous persons of diplomatic status" other than those already listed by the previous sub-paragraphs of Article 11(2)(b) ${ }^{82}$ Others, by contrast, have noted that the facially unambiguous text of sub-paragraph (iv) weighs in favour of a literal reading of this provision. ${ }^{83}$ This issue was touched upon by the UK Supreme Court in Benkharbouche, which leaned towards the literal construction of sub-paragraph (iv). ${ }^{84}$ Crucially, though, the Supreme Court also stated that sub-paragraph (iv) was irrelevant for the purpose of a Cudak-like proportionality assessment of grants of immunity. This is because, after a survey of state practice, the Supreme Court concluded that this provision does not reflect the content of customary international law. In the Court's words: "if article 11(2)(b)(iv) means what it says, it is legislative rather than declaratory of existing international law. It may one day bind states qua treaty. It may come to represent customary international law if and when the Convention attracts sufficient support. But it does not do either of these things as matters presently stand". 85

A final reason suggesting that the ECtHR should be more cautious in affirming that Article 11 corresponds to general international law in its entirety has to do with the impact of the Court's jurisprudence over the case law of national courts. The ECtHR's case law incentivises domestic courts to apply Article 11 UNCSI in order to assess whether they have jurisdiction over employment lawsuits involving foreign states, and this for mainly two reasons: firstly, because the Strasbourg Court's assessment of customary international law may be seen by domestic courts as highly authoritative; and secondly, because applying Article 11 is a way for a do-

\footnotetext{
${ }^{82}$ FOAKES, J.; O'KEEFE, R. Article 11. In: O'KEEFE, R.; TAMS, C. (ed.). The United Nations Convention on Jurisdictional Immunities of States and Their Property: A Commentary. Oxford: Oxford University Press, 2013. p. 201.

83 PAVONI, R. The Myth of the Customary Nature of the United Nations Convention on State Immunity: Does the End Justify the Means? In: VAN AAKEN, A.; MOTOC, I. (ed.), European Convention on Human Rights and General International Law. Oxford: Oxford University Press, 2018. p. 274-276.

${ }^{84}$ SUPREME COURT (UK), Benkharbouche v. Secretary of State for Foreign and Commonwealth Affairs and Secretary of State for Foreign and Commonwealth Affairs and Libya v. Janah, 18 October 2017, [2017] UKSC 62, para. 72.

85 SUPREME COURT (UK), Benkharbouche v. Secretary of State for Foreign and Commonwealth Affairs and Secretary of State for Foreign and Commonwealth Affairs and Libya v. Janah, 18 October 2017, [2017] UKSC 62, para. 72.
}

mestic court to be on the safe side and avoid future condemnations of its own state by the ECtHR. As seen in the previous Section, this has already occurred inter alia in Italy and France, whose Courts of Cassation have applied Article 11 qua customary law citing ECtHR case law as sole or primary authority. Crucially, though, the application of Article 11 by national courts may not necessarily be a positive development. While it would undoubtedly be so in cases where a national judiciary applies an absolute or quasi-absolute doctrine of state immunity in the context of employment disputes, not all the countries of the Council of Europe subscribe to an immunity more extensive than that envisioned by Article 11: certain national approaches may be, in some or all respects, more favourable than Article 11 to the employees' right of access to a court. In such cases, the application of Article 11 constitutes a regressive development in these states' domestic practice.

Italy provides an example in point. Before starting applying Article 11, the Italian courts commonly followed an approach whereby jurisdiction over labour lawsuits against foreign states would be exercised when either of these requirements was met: (i) the employee did not perform functions in the exercise of governmental authority, or (ii) the plaintiff, regardless of his/ her functions, only requested monetary compensation (to the exception of lawsuits for damages for unlawful dismissal, which were mostly treated as immune). ${ }^{86}$ Hence, the Italian courts could previously uphold their jurisdiction over pecuniary claims by foreign states' employees exercising governmental functions, something that is now precluded under Article 11(2)(a). Furthermore, while the previous Italian case law was utterly indifferent to the nationality and residence of the plaintiff employee, ${ }^{87}$ the application of Article 11 currently prevents nationals of the employer state who work in Italy but do not permanently reside there from bringing their claims before the Italian courts. Recent Italian case law reveals that the one positive deriving from the application of Article 11 is that the Italian courts have modified their position on claims for damages for wrongful

\footnotetext{
${ }^{86}$ See more extensively PAVONI, R. La jurisprudence italienne sur l'immunité des États dans les différends en matière de travail: tendances récentes à la lumière de la Convention des Nations Unies. $A n$ nuaire français de droit international, v. 53, 2007.

87 PAVONI, R. La jurisprudence italienne sur l'immunité des États dans les différends en matière de travail: tendances récentes à la lumière de la Convention des Nations Unies. Annuaire français de droit international, v. 53, 2007. p. 219.
} 
dismissal, which are now considered to be amenable to Italian jurisdiction. ${ }^{88}$

\section{The risk of leaving state employees without means of redress}

A final problematic aspect of the ECtHR's jurisprudence is that, in cases where a grant of immunity is considered to be compatible with Article 11 UNCSI and thus with Article 6 ECHR, an employee may be left de facto without any effective means of redress.

Consider, once again, the Court's judgment in the Ndayegamiye case. One of the points raised by the applicant was that, by declaring Burundi to be immune from suit, the Swiss courts had left her without any judicial means of obtaining redress. She acknowledged that in the past she had brought a complaint relating to her employment before the Burundian authorities, but submitted, firstly, that such remedy was only administrative and not judicial in nature, and secondly, that it was not available to her anymore due to changes in Burundi's political leadership. ${ }^{89}$ The Court disposed of this argument by noting that the employee had in fact access to the courts of her state of nationality. It was satisfied by the fact that, during the proceedings before the Swiss courts, Burundi had given "reassurances" that the Administrative Court of Bujumbura was competent to adjudicate the dispute and that the applicant's claims were not time-barred according to the law of Burundi. ${ }^{90}$ In this respect, too, the Court followed in the footsteps of the ILC. Commenting on the antecedent of Article 11(2)(e), the Commission wrote that, for employees covered by this provision, "[r]emedies and access to courts exist in the employer state". ${ }^{91}$

In all truth, to affirm the the courts of the employer state can always hear disputes brought by sta-

\footnotetext{
88 See for example CORTE DI CASSAZIONE (Italy), Académie de France à Rome v. Galamini di Recanati, 17 June 2014, No. 19674, ILDC 2437 (IT 2014); CORTE DI CASSAZIONE (Italy), Chibomba v. Embassy of the Republic of Zambia to the Italian Republic, 6 June 2017, No. 13980, ILDC 2703 (IT 2017).

89 ECtHR. Ndayegamiye-Mporamazina v. Switzerland, 5 February 2019, App. No. 16874/12, para. 43.

${ }^{0}$ ECtHR. Ndayegamiye-Mporamazina v. Switzerland, 5 February 2019, App. No. 16874/12, para. 64.

${ }^{91}$ INTERNATIONAL LAW COMMISSION, Draft Articles on Jurisdictional Immunities of States and Their Property, with commentaries. 1991. Yearbook of the International Law Commission, v. II (Two). para. 12.
}

te employees is an unproven assumption: it neglects to consider that, in certain countries, the government may never be sued in court either de jure or de facto, ${ }^{92}$ or that various procedural obstacles may prevent such a claim from being adjudicated. But even assuming that Burundi's generic reassurances sufficed to prove that a judicial remedy of some kind was actually available to the applicant, which is itself disputable, the Strasbourg Court failed to perform any inquiry into the effectiveness of such remedy. A judicial remedy may not necessarily meet basic requirements of fair trial under Article 6 ECHR. For example, courts in some countries may not be sufficiently independent from the government to rule impartially over a dispute between high-ranking employees and the state. This would be highly problematic because, according to the ECtHR's jurisprudence, independence, impartiality and establishment by law are core elements of fair trial. ${ }^{93}$ Furthermore, it should be considered that bringing an employment claim before the courts of a state other than the one where the work is performed may entail a host of practical difficulties (e.g. the moving of witnesses or the recruitment of local attorneys) which may cause excessive costs. This may run counter to the principle whereby a prohibitive cost of the proceedings, in view of the individual's financial capacity, can entail a breach of the right of access to justice. ${ }^{94}$

The likely reason why the ECtHR paid insufficient attention to these problematic aspects is that - as it expressly made clear - the Court did not consider the issue of the availability of effective alternative remedies to be decisive: the Ndayegamiye judgment restated the Court's official position that "la compatibilité de l'octroi de l'immunité de juridiction à un État avec l'article 6 $\int 1$ de la Convention ne dépend pas de l'existence d'alternatives raisonnables pour la résolution du litige". ${ }^{95}$

92 FOAKES, J.; O'KEEFE, R. Article 11. In: O'KEEFE, R.; TAMS, C. (ed.). The United Nations Convention on Jurisdictional Immunities of States and Their Property: A Commentary. Oxford: Oxford University Press, 2013. p. 206.

93 SCHABAS, W.A. The European Convention on Human Rights: A Commentary. Oxford: Oxford University Press, 2015. p. 294-296.

${ }^{94}$ See, e.g., ECtHR. Harrison McKee v. Hungary, 3 June 2014, App. No. 22840/07, para. 25, with regard to court fees.

95 ECtHR. Ndayegamiye-Mporamazina v. Switzerland, 5 February 2019, App. No. 16874/12, para. 64. See ECtHR. Stichting Mothers of Srebrenica and Others v. the Netherlands, 11 June 2013, App. No. 65542/12, para. 164: "It does not follow, however, that in the absence of an alternative remedy the recognition of immunity is ipso facto constitutive of a violation of the right of access to a court". 
This approach has been the subject of criticism in legal scholarship. ${ }^{96}$ For the purposes of the present discussion, it may be sufficient to note that it runs counter to one of the tenets of the ECtHR's jurisprudence on the relationship between immunities and access to justice, i.e. that limitations on the latter are admissible as long as they do not impair the essence of the right. ${ }^{97}$ But regardless of whether the Court's general approach to alternative remedies in the context of state immunity is justified - a question which largely exceeds the scope of this paper - at a minimum the Court's jurisprudence creates a blatant discrimination problem. While a Burundian employee residing in Switzerland would be allowed to sue Burundi before the labour courts of Geneva, the applicant in Ndayegamiye, a Burundian resident of a French village bordering Switzerland, is expected to bring her case before the courts of Burundi. The two employees may work in the exact same role and be living a few kilometers apart. It is hard to make sense of such a blatant disparity of treatment. It would probably be more reasonable to treat like cases alike and to allow all employees permanently working - not residing - in the state of the forum to bring suits before such state's courts, provided the other requirements for the exercise of the local courts' jurisdiction are met.

This would appear more coherent with what the ECtHR itself stated in other cases regarding state immunity and employment. For example, in the aforementioned case of Cudak v. Lithuania, the respondent government argued that the applicant could have brought her claims before the courts of Poland, her employer state. The Polish courts had jurisdiction and would have applied Lithuanian law pursuant to a choice-of-law clause contained in the employment contract. The respondent state also took care to demonstrate that, by virtue of $\mathrm{Li}$ thuanian law, the applicant's claim was not time-barred. ${ }^{98}$

\footnotetext{
96 See, for example, PAPA, M.I. The Mothers of Srebrenica Case before the European Court of Human Rights: United Nations Immunity versus Right of Access to a Court. Journal of International Criminal Justice, v. 14, n. 4, 2016; PAVONI, R. Human Rights and the Immunities of Foreign States and International Organizations. In: DE WET, E.; VIDMAR, J. (ed.). Hierarchy in International Law: The Place of Human Rights. Oxford: Oxford University Press, 2012.

${ }^{97}$ See ECtHR. Ndayegamiye-Mporamazina v. Switzerland, 5 February 2019, App. No. 16874/12, para. 51: "[la Cour] se doit de vérifier que les limitations mises en œuvre ne restreignent pas l'accès offert à l'individu d'une manière ou à un point tels que le droit s'en trouve atteint dans sa substance même".

98 ECtHR, Cudak v. Lithuania, 23 March 2010, (GC), App. No. $15869 / 02$, para. 34 .
}

In respect to this argument, the Court noted that "such a remedy, even supposing that it was theoretically available, was not a particularly realistic one in the circumstances of the case. If the applicant had been required to use such a remedy she would have encountered serious practical difficulties which would have been incompatible with her right of access to a court, which, like all other rights in the Convention, must be interpreted so as to make it practical and effective, not theoretical or illusory". ${ }^{99}$ These remarks by the Court were realistic and on point. But it defies logic that, while Polish courts were not considered to be a reasonable alternative to the courts of Lithuania, Burundian courts were treated as a reasonable alternative to those of Switzerland.

The Court's approach to the problem of the lack of alternative remedies also stands in sharp contrast with its jurisprudence on the immunity of international organizations in employment disputes. ${ }^{100}$ Starting from the landmark judgments in Waite and Kennedy and Beer and Reagan, the Court has affirmed that a "material factor" in assessing the compatibility of grants of immunity with Article 6 ECHR is "whether the applicants had available to them reasonable alternative means to protect effectively their rights under the Convention". ${ }^{101}$ Admittedly, also in the area of international organization immunity the Court does not consider this principle to be absolute: most notably, in the Mothers of Srebrenica case, the Court controversially rejected a claim that granting immunity to the United Nations in lack of alternative means of redress amounted to a breach of Article $6 .{ }^{102}$ Crucially, though, the Court has never made any exceptions to the alternative remedies test in the case of employment disputes, which suggests that it considers that international organizations' employees

99 ECtHR. Cudak v. Lithuania, 23 March 2010, (GC), App. No. 15869/02, para. 36 .

100 See ARAÚJO, Kallás; CAETANO, F. A imunidade de jurisdição das organizações internacionais face ao direito de acesso à justiça. Brazilian Journal of International Law, v. 13, n. 3, 2016.

101 ECtHR. Waite and Kennedy v. Germany, 18 February 1999, App. No. 26083/94, para. 68; ECtHR. Beer and Reagan v. Germany, 18 February 1999, App. No. 28934/95, para. 58. See extensively SCHMITT, P. Access to Justice and International Organizations: The Case of Individual Victims of Human Rights Violations. Cheltenham: Edward Elgar, 2017; REINISCH, A.; WEBER, U.A. In the Shadow of Waite and Kennedy - The Jurisdictional Immunity of International Organizations, the Individual's Right of Access to the Courts and Administrative Tribunals as Alternative Means of Dispute Settlement. International Organizations Law Review, v. 1, 2004.

102 ECtHR. Stichting Mothers of Srebrenica and Others v. the Netherlands, 11 June 2013, App. No. 65542/12. 
should always have a means of redress. Once again, this creates a blatant discrimination problem between the position of such employees and that of individuals in the employ of foreign states.

\section{Conclusions}

This paper analyzed the ECtHR's jurisprudence on the compatibility between the right of access to a court, protected under Article $6 \mathrm{ECHR}$, and state immunity in the context of labour claims, i.e. claims brought by individuals working for a foreign state in the territory of the state of the forum. As has been seen, the main feature of the Court's approach in this area is the use of Article 11, on contracts of employment, of the UN Convention on State Immunity as a yardstick of proportionality of such grants of immunity. A respondent state is deemed not to have violated the ECHR if it recognised to the employer state an immunity which falls within the boundaries of Article 11, while an immunity broader than required by Article 11 constitutes a violation of the applicant's right of access to justice. The Court's use of this provision is based on the assumption that it reflects the status of customary international law in its entirety. Since the UNCSI has not yet entered into force, Article 11 is not binding qua treaty law.

While acknowledging that the ECtHR's case law on this subject has in many respects contributed to providing state employees with broader access to the courts of the states where their work is performed, this paper nonetheless pointed to three serious pitfalls of the Court's approach.

Firstly, the assumption that Article 11 constitutes a verbatim codification of international custom is for the most part unpersuasive. The ILC, which was credited by the ECtHR with affirming that Article 11 was meant to reflect the existing practice of states, never actually said that, nor does the Court's assessment find confirmation in the rest of the travaux préparatoires. Moreover, the ECtHR has never conducted any autonomous survey of state practice with a view to verifying to what extent the various provisions of Article 11 are really reflective of general international law.

Secondly, the use of Article 11 by way of codification of customary law negatively impacts on the scope of the right of access to a court because several pro- visions of this article lay down an immunity broader than custom requires. The paper pointed to two clauses - paragraph 2(e) and paragraph 2(b)(iv) - as examples of provisions whose support in state practice is too thin for them to be considered codificatory. The application of Article 11 in domestic judicial proceedings, under the influence of the ECtHR, may also cause adverse effects in countries whose approach to state immunity in labour claims is, at least in some respects, more restrictive than that adopted by Article 11 .

Thirdly, insufficient consideration has been given by the ECtHR to the fact that, in cases where any of the Article 11's grounds of immunity applies, state employees may be left without any judicial means of obtaining redress. Although the Court argued in the Ndayegamiye case that, in such cases, an employee would always have access to the courts of the employer state, it has been seen how the availability and the effectiveness of such a remedy should not be taken for granted and that, in any event, the Court's approach may give rise to unreasonable discrimination between employees. To be true to its long-standing jurisprudence according to which the right of access to a court should be effective and not merely illusory, it is of great importance that the ECtHR addresses such flaws in the handling of future cases.

\section{References}

ARAÚJO, Kallás; CAETANO, F. A imunidade de jurisdição das organizações internacionais face ao direito de acesso à justiça. Brazilian Journal of International Law, v. 13, n. 3, 2016.

BONAFÈ, B.I. The ECHR and the Immunities Provided by International Law. Italian Yearbook of International Law, v. 20, 2010.

CORTE DI CASSAZIONE (Italy), Académie de France à Rome v. Galamini di Recanati, 17 June 2014, No. 19674, ILDC 2437 (IT 2014).

CORTE DI CASSAZIONE (Italy), Chibomba v. Embassy of the Republic of Zambia to the Italian Republic, 6 June 2017, No. 13980, ILDC 2703 (IT 2017).

CORTE DI CASSAZIONE (Italy), Embassy of Spain to the Holy See v. De la Grana Gonzales, 11 March 2014, No. 9034, ILDC 2436 (IT 2014). 
COUR DE CASSATION (France), B v. Republic of Ghana, 27 November 2019, No. 18-13790, ILDC 3070 (FR 2019).

DE VITTOR, F. Recenti sviluppi in tema di immunità degli Stati dalla giurisdizione: la Convenzione di New York del 2 dicembre 2004. In: LANCIOTTI, A.; TANZI, A. (ed.), Le immunità nel diritto internazionale. Temi scelti. Torino: Giappichelli, 2007.

EUROPEAN COURT OF HUMAN RIGHTS. AlAdsani v. United Kingdom, 21 November 2001, (GC), App. No. 35763/97.

EUROPEAN COURT OF HUMAN RIGHTS. Beer and Reagan v. Germany, 18 February 1999, App. No. 28934/95.

EUROPEAN COURT OF HUMAN RIGHTS. Cudak v. Lithuania, 23 March 2010, (GC), App. No. 15869/02.

EUROPEAN COURT OF HUMAN RIGHTS. Fogarty v. United Kingdom, 21 November 2001, (GC), App. No. 37112/97.

EUROPEAN COURT OF HUMAN RIGHTS. Guadagnino v. Italy and France, 18 January 2011, App. No. 2555/03.

EUROPEAN COURT OF HUMAN RIGHTS. Harrison McKee v. Hungary, 3 June 2014, App. No. 22840/07.

EUROPEAN COURT OF HUMAN RIGHTS. Nä̈tLitman v. Switzerland, 15 March 2018, App. No. 51357/07.

EUROPEAN COURT OF HUMAN RIGHTS. Naku v. Lithuania and Sweden, 8 November 2016, App. No. 26126/07.

EUROPEAN COURT OF HUMAN RIGHTS. Ndayegamiye-Mporamazina v. Switzerland, 5 February 2019, App. No. $16874 / 12$.

EUROPEAN COURT OF HUMAN RIGHTS. Radunovic and Others v. Montenegro, 25 October 2016, App. Nos. 45197/13, 53000/13 and 73404/13.

EUROPEAN COURT OF HUMAN RIGHTS. Sabeh El Leil v. France, 29 June 2011, App. No. 34869/05.

EUROPEAN COURT OF HUMAN RIGHTS. Stichting Mothers of Srebrenica and Others v. the Netherlands, 11 June 2013, App. No. 65542/12.

EUROPEAN COURT OF HUMAN RIGHTS. Waite and Kennedy v. Germany, 18 February 1999, App. No. 26083/94.
EUROPEAN COURT OF HUMAN RIGHTS. Wallishauser v. Austria, 17 July 2012, App. No. 156/04.

FOAKES, J.; O'KEEFE, R. Article 11. In: O'KEEFE, R.; TAMS, C. (ed.). The United Nations Convention on Jurisdictional Immunities of States and Their Property: A Commentary. Oxford: Oxford University Press, 2013.

FOX, H.; WEBB, P. The Law of State Immunity. Third edition. Oxford: Oxford University Press, 2013.

FRANCIONI, F. The Rights of Access to Justice under Customary International Law, in: FRANCIONI, F. (ed.). Access to Justice as a Human Right. Oxford: Oxford University Press, 2007.

GARNETT, R. State and Diplomatic Immunity and Employment Rights: European Law to the Rescue? International \& Comparative Law Quarterly, v. 64, 2015.

HAFNER, G. Historical Background of the Convention. In: O'KEEFE, R.; TAMS, C. (ed.). The United Nations Convention on Jurisdictional Immunities of States and Their Property: A Commentary. Oxford: Oxford University Press, 2013.

HIGGINS, R. Certain Unresolved Aspects of the Law of State Immunity. Netherlands International Law Review, v. 29, p. 265-276, 1982.

HIGH COURT OF CASSATION AND JUSTICE (Romania), SDG v. Canada and Prosecutor General (joining), 1 April 2003, No. 1292, ILDC 1024 (RO 2003).

HUMAN RIGHTS COMMITTEE. General Comment No. 32: Article 14: Right to equality before courts and tribunals and to a fair trial, 23 August 2007, CCPR/C/ GC/32.

INTER-AMERICAN COURT OF HUMAN RIGHTS. Barbani Duarte et al. v. Uruguay, 13 October 2011, Series C No. 234.

INTERNATIONAL COURT OFJUSTICE. Armed Activities on the Territory of the Congo (Democratic Republic of the Congo v. Uganda), Judgment, 2005. Available at: https:// www.icj-cij.org/public/files/case-related/116/11620051219-JUD-01-00-EN.pdf. Accessed on: 6 Mayo 2021.

INTERNATIONAL COURT OF JUSTICE. JurisdictionalImmunities of the State (Germany v. Italy: Greece intervening). Judgment, 2012. Available at: https://www.icj-cij.org/ public/files/case-related/143/143-20120203-JUD-0100-EN.pdf. Accessed on: 6 Mayo 2021. 
INTERNATIONAL COURT OF JUSTICE. Military and Paramilitary Activities in and against Nicaragua (Nicaragua v. United States of America). Merits, Judgment, 1986. Available at: https://www.icj-cij.org/public/files/caserelated/70/070-19860627-JUD-01-00-EN.pdf. Accessed on: 6 Mayo 2021.

INTERNATIONAL COURT OF JUSTICE. North Sea Continental Shelf Cases (Federal Republic of Germany/Denmark; Federal Republic of Germany/Netherlands). Judgment, 1969. Available at: https://www.icj-cij.org/public/ files/case-related/52/052-19690220-JUD-01-00-EN. pdf. Accessed on: 6 Mayo 2021.

INTERNATIONAL COURT OF JUSTICE. Oil Platforms (Islamic Republic of Iran v. United States of America), Preliminary Objection, Judgment, 1996. Available at: https://www.icj-cij.org/public/files/caserelated/90/090-19961212-JUD-01-00-EN.pdf. Accessed on: 6 Mayo 2021.

INTERNATIONAL COURT OF JUSTICE. Statute of the International Court of Justice. Available at: https:// www.icj-cij.org/en/statute. Accessed on: 6 Mayo 2021.

INTERNATIONAL LAW COMMISSION. Draft Articles on Jurisdictional Immunities of States and Their Property, with commentaries. 1991. Yearbook of the International Law Commission, v. II (Two).

INTERNATIONAL LAW COMMISSION. Draft conclusions on identification of customary international law, with commentaries. 2018. Yearbook of the International Law Commission, v. II (Two).

INTERNATIONAL LAW COMMISSION. Statute of the International Law Commission. Available at: https:// legal.un.org/ilc/texts/instruments/english/statute/ statute.pdf. Accessed on: 6 Mayo 2021.

IOVANE, M. Conflicts Between State-Centred and $\mathrm{Hu}-$ man-Centred International Norms. In: PISILLO MAZZESCHI, R., De Sena, P. (ed.), Global Justice, Human Rights and the Modernization of International Law. Cham: Springer, 2018.

IOVANE, M. L'influence de la multiplication des juridictions internationales sur l'application du droit international. Recueil des Cours: collected courses of The Hague Academy of International Law. Kluwer Law International, Hague, v. 383, 2017.
KLOTH, M. Immunities and the Right of Access to Court under Article 6 of the European Convention on Human Rights. Leiden - Boston: Nijhoff, 2010.

KÖHLER, U. Contracts of Employment under the UN Convention on Jurisdictional Immunities of States and Their Property. Austrian Review of International and European Law, v. 9, 2004.

LABOUR COURT OF BRUSSELS (Belgium). Kingdom of Morocco v. DR, 6 November 1989, 115 ILR 421.

LUSA BORDIN, F. Reflections of Customary International Law: The Authority of Codification Conventions and ILC Draft Articles in International Law. International \& Comparative Law Quarterly, v. 63, 2014.

NIGRO, R. Immunità degli Stati e diritto di accesso al giudice: un nuovo approccio nel diritto internazionale? Rivista di diritto internazionale, v. 96, n. 3, 2013.

PAPA, M.I. The Mothers of Srebrenica Case before the European Court of Human Rights: United Nations Immunity versus Right of Access to a Court. Journal of International Criminal Justice, v. 14, n. 4, 2016.

PAVONI, R. Human Rights and the Immunities of Foreign States and International Organizations. In: DE WET, E.; VIDMAR, J. (ed.). Hierarchy in International Law: The Place of Human Rights. Oxford: Oxford University Press, 2012.

PAVONI, R. La jurisprudence italienne sur l'immunité des États dans les différends en matière de travail: tendances récentes à la lumière de la Convention des $\mathrm{Na}$ tions Unies. Annuaire français de droit international, v. 53, 2007.

PAVONI, R. The Myth of the Customary Nature of the United Nations Convention on State Immunity: Does the End Justify the Means? In: VAN AAKEN, A.; MOTOC, I. (ed.), European Convention on Human Rights and General International Law. Oxford: Oxford University Press, 2018.

REINISCH, A.; WEBER, U.A. In the Shadow of Waite and Kennedy - The Jurisdictional Immunity of International Organizations, the Individual's Right of Access to the Courts and Administrative Tribunals as Alternative Means of Dispute Settlement. International Organizations Law Review, v. 1, 2004.

ROSSI, P. Controversie di lavoro e immunità degli Stati esteri: tra codificazione e sviluppo del diritto consuetudinario. Rivista di diritto internazionale, v. 102, n. 1, 2019. 
ROSSI, P. International Law Immunities and Employment Claims: A Critical Appraisal. Oxford: Hart Publishing, forthcoming.

SCHABAS, W.A. The European Convention on Human Rights: A Commentary. Oxford: Oxford University Press, 2015.

SCHMIT'T, P. Access to Justice and International Organizations: The Case of Individual Victims of Human Rights Violations. Cheltenham: Edward Elgar, 2017.

SHELTON, D. Remedies in International Human Rights Law. 3rd edn. Oxford: Oxford University Press, 2015.

SINCLAIR, I. The Law of Sovereign Immunity: Recent Developments. Recueil des Cours: collected courses of The Hague Academy of International Law. Kluwer Law International, Hague, v. 176, 1980.

SUCHARITKUL, S. Developments and Prospects of the Doctrine of State Immunity: Some Aspects of Codification and Progressive Development. Netherlands International Law Review, v. 29, 1982.

SUCHARITKUL, S. Fifth Report on Jurisdictional Immunities of States and Their Property. 1983. Yearbook of the International Law Commission, v. II (One).

SUPREME COURT (Austria). French Consular Employee Claim Case, 14 June 1989, Case No. 9 Ob A 170/89, 86 ILR 583.

SUPREME COURT (UK). Benkharbouche v. Secretary of State for Foreign and Commonwealth Affairs and Secretary of State for Foreign and Commonwealth Affairs and Libya v. Janah, 18 October 2017, [2017] UKSC 62.

WEBB, P. The Immunity of States, Diplomats and International Organizations in Employment Disputes: The New Human Rights Dilemma? European Journal of International Law, v. 27, n. 3, 2016.

WOOD, M. Third Report on identification of customary international law. UN Doc. A/CN.4/682, 27 March 2015.

YANG, X. State Immunity in International Law. Cambridge: Cambridge University Press, 2012. 
Para publicar na Revista de Direito Internacional, acesse o endereço eletrônico www.rdi.uniceub.br ou www.brazilianjournal.org.

Observe as normas de publicação, para facilitar e agilizar o trabalho de edição. 